Article

\title{
Human Activities, Biostratigraphy and Past Environment Revealed by Small-Mammal Associations at the Chalcolithic Levels of El Portalón de Cueva Mayor (Atapuerca, Spain)
}

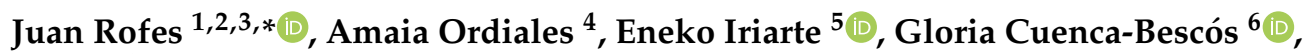 \\ María Ángeles Galindo-Pellicena ${ }^{7,8,9}$, Amalia Pérez-Romero ${ }^{5}$, José Miguel Carretero ${ }^{5}$ and Juan Luis Arsuaga ${ }^{9}$ \\ check for \\ updates \\ Citation: Rofes, J.; Ordiales, A.; \\ Iriarte, E.; Cuenca-Bescós, G.; \\ Galindo-Pellicena, M.Á.; \\ Pérez-Romero, A.; Carretero, J.M.; \\ Arsuaga, J.L. Human Activities, \\ Biostratigraphy and Past \\ 1 Archaeological Studies Program, University of the Philippines-Diliman, Albert Hall, Lakandula St., \\ Quezon City 1101, Philippines \\ 2 Archéozoologie, Archéobotanique: Sociétés, Pratiques et Environnements (AASPE, UMR 7209), \\ Sorbonne Universités, Muséum National d'Histoire Naturelle, CNRS, CP56, 55 rue Buffon, \\ F-75005 Paris, France \\ 3 National Museum of the Philippines, P. Burgos Drive, City of Manila 1000, Philippines \\ 4 Independent Researcher, Barrio Ergoien 60C, 48113 Gamiz-Fika, Spain; amaiaocb@gmail.com \\ 5 Laboratorio de Evolución Humana, Departamento de Historia, Geografía y Comunicación, \\ Universidad de Burgos, Edificio I+D+i, Plaza de Misael Bañuelos s/n, 09001 Burgos, Spain; \\ eiriarte@ubu.es (E.I.); apromero14@gmail.com (A.P.-R.); jmcarre@ubu.es (J.M.C.) \\ 6 Aragosaurus-IUCA-Earth Sciences Department, University of Zaragoza, C/Pedro Cerbuna 12, \\ 50009 Zaragoza, Spain; cuencag@unizar.es \\ 7 Museo Arqueológico Regional, Plaza de Las Bernardas s/n, Alcalá de Henares, 28801 Madrid, Spain; \\ mangeles.galindo@fgua.es \\ 8 Fundación General de la Universidad de Alcalá de Henares, C/Imagen 3, Alcalá de Henares, \\ 28801 Madrid, Spain \\ 9 Centro Mixto UCM-ISCIII de Evolución y Comportamiento Humanos, C/Monforte de Lemos 5, Pabellón 14, \\ 28029 Madrid, Spain; jlarsuaga@isciiii.es \\ * Correspondence: jcrofes@up.edu.ph
} Environment Revealed by Small-Mammal Associations at the Chalcolithic Levels of El Portalón de Cueva Mayor (Atapuerca, Spain). Quaternary 2021, 4, 16. https:/ / doi.org/10.3390/quat4020016

Academic Editor: Jef Vandenberghe

Received: 12 April 2021

Accepted: 11 May 2021

Published: 14 May 2021

Publisher's Note: MDPI stays neutral with regard to jurisdictional claims in published maps and institutional affiliations.

Copyright: (c) 2021 by the authors. Licensee MDPI, Basel, Switzerland. This article is an open access article distributed under the terms and conditions of the Creative Commons Attribution (CC BY) license (https:/ / creativecommons.org/licenses/by/ $4.0 /)$.
Abstract: The Chalcolithic levels of El Portalón de Cueva Mayor (Atapuerca, Burgos, Spain) offer a good opportunity to test whether the small-mammal contents of different archaeo-stratigraphical units may be useful to characterize them as independent entities. With that purpose, we studied representative samples of small-mammal remains from the two main contexts identified: the Early Chalcolithic (EC) funerary context and the Late Chalcolithic (LC) habitat/stabling context, with the latter comprising three different archaeological units according to their origin, namely prepared floors, activity floors and stabling surfaces or fumiers. Following the distribution of taxa in their respective contexts, we performed several statistical tests to check for significant discrepancies between archaeological units. The exclusive presence of certain taxa, together with the statistical difference in relative taxonomic ratios, points to the integrity and unpolluted condition of the EC context. The interspersed arrangement of the different LC context's units made them prone to inter-pollution as they are not statistically different. The unexpected presence of Pliomys lenki and Chionomys nivalis in the prepared floors evidences their Upper Pleistocene allochthonous origin. The EC levels of El Portalón contribute the first Holocene records of nine taxa in the Sierra de Atapuerca. An environment dominated by woodland, shrubland and wet meadows, with moderate presence of grassland, inland wetlands and rocky areas, is inferred from the small-mammal association of the EC levels.

Keywords: small mammals; archaeological contexts; Chalcolithic; biostratigraphy; past environment; Holocene; Sierra de Atapuerca; Iberian Peninsula

\section{Introduction}

The fossil remains of small vertebrates are frequently preserved in archaeological and paleontological contexts such as cave and rock shelter deposits, sometimes in association 
with human remains and artefacts. Contrary to their larger counterparts, which are usually a product of human selection, the small-vertebrate accumulations mainly result from digestion or storing by their predators (i.e., birds of prey and small carnivores) or natural death Despite unavoidable filters due to specific predators [1-3], they reflect local biocenoses reasonably well. The presence or absence and relative abundance of small-mammal species can thus be used as proxies for biochronology (e.g., References [4,5]) and for the reconstruction of both past environments (e.g., References [6-10]) and biogeographical histories (e.g., References [11,12]).

Such interpretations are based on the working hypothesis of a strict contemporary association between small vertebrates and archaeological remains, implying good archaeological coherence of the analysed assemblages. There are exceptions to this hypothesis, i.e., some post-depositional processes can affect the stratigraphy of a given site by altering the integrity of the deposits $[13,14]$ and, therefore, the subsequent scientific interpretations. For instance, caves and rock shelters are propitious places for small- and medium-sized animals to nest or build burrows, which may significantly modify and pollute faunal assemblages [15-17]. The tiny size of small-vertebrate remains favors percolations into underlying layers along stratigraphic sequences, and this is a known phenomenon in given archaeological deposits [18].

The Chalcolithic levels of El Portalón de Cueva Mayor (Atapuerca, Burgos, Spain) offer a unique opportunity to test whether the small-mammal contents of different archaeostratigraphical units may be useful to characterize them as independent entities (for biostratigraphical, biogeographical and paleo-environmental interpretations), and, if so, to what extent. For this purpose, we depart from a working hypothesis opposite to the one previously mentioned: there was (some degree of) pollution among units. Is this true? Moreover, even if so, is it still possible to distinguish and characterize archaeostratigraphical units/contexts according to their respective small-mammal contents?

To answer these questions, we have studied representative samples of small-mammal remains from the two main archaeo-stratigraphical contexts identified in the Chalcolithic levels of El Portalón: the Early Chalcolithic (EC) funerary context and the Late Chalcolithic (LC) habitat/stabling context, with the latter comprising three different archaeological units according to their origin, namely prepared floors, activity floors and stabling surfaces or fumiers. Following the taxonomical identification, we performed several statistical tests to check for significant discrepancies between contexts and archaeological units. Relevant biostratigraphic and environmental insights are also given.

Preliminary results of this work were presented elsewhere [19], but they were substantially revised and improved here.

\section{Materials and Methods}

\subsection{The Site}

El Portalón is located at the current entrance to the Cueva Mayor-Cueva del Silo karst system of the Sierra de Atapuerca (Burgos, Spain) (Figure 1). The latter is internationally well-known for its Pleistocene hominin-bearing localities [20-23], but also provides a rich stratigraphic record from the Holocene [24-31]. The relevance of El Portalón relies on its long human occupation, documented from the Paleolithic to historic times (from ca. $35,205 \mathrm{yr}$ cal BP to $796 \mathrm{yr}$ cal BP) [24,26-29]. El Portalón site alone currently surpasses $200 \mathrm{~m}^{2}$. However, this space is part of a much larger endokarstic archaeological area that comprises the room known as Salón del Coro or Galería Principal (which is part of El Portalón site itself) and the Galería del Sílex (Figure 1b,c). 


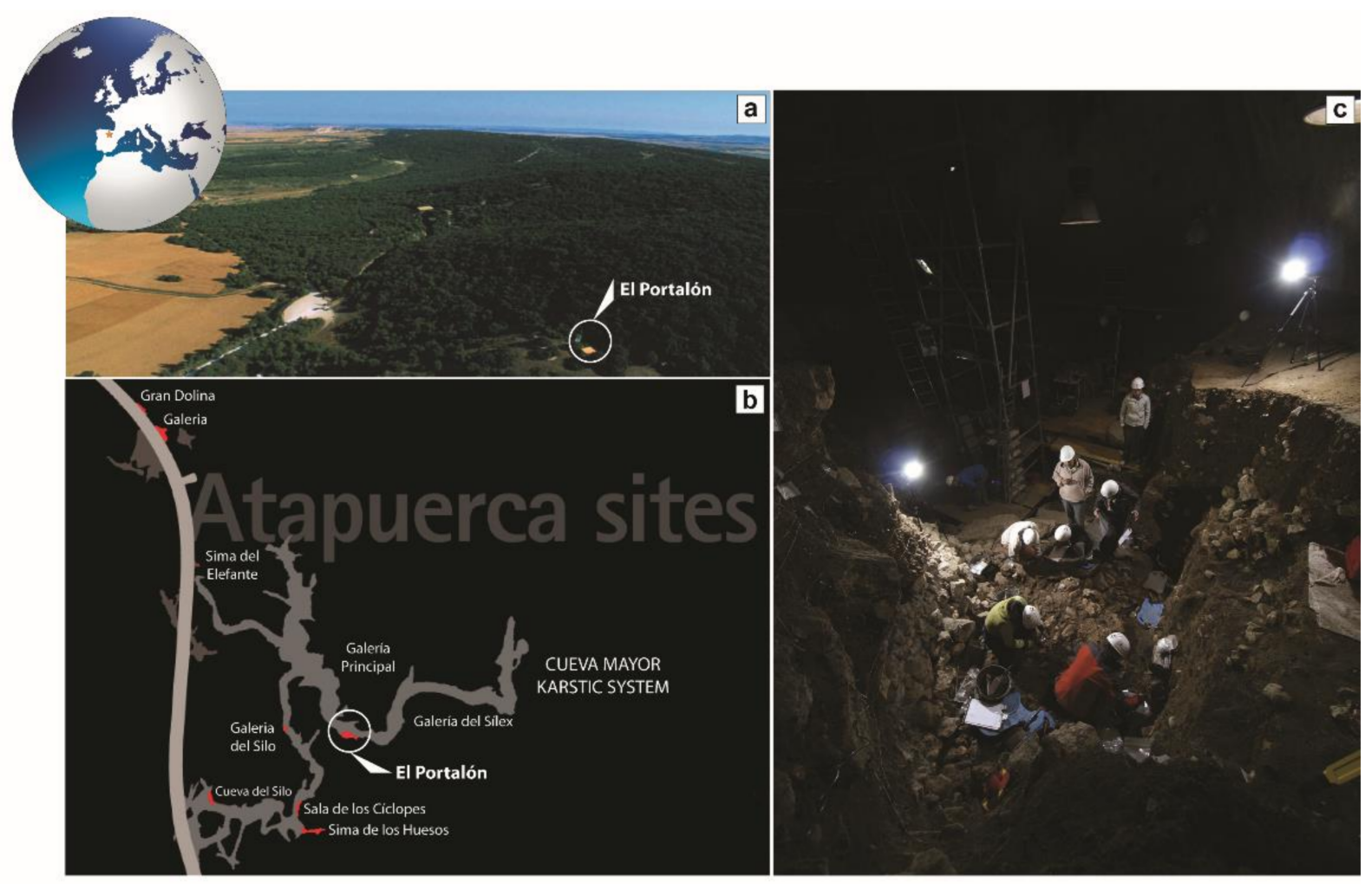

Figure 1. Location of El Portalón de Cueva Mayor archaeological site. (a) Location of the site in the Sierra de Atapuerca; (b) location of the site at the entrance of the Cueva Mayor-Cueva del Silo karstic system (plan view), with the latter containing numerous Lower Pleistocene to Holocene archaeo-paleontological sites (in red); (c) general view of the works during the excavation of the early Chalcolithic funerary tumulus (ca. $5000 \mathrm{yr}$ cal BP).

The currently known stratigraphic sequence of El Portalón exceeds $10 \mathrm{~m}$ and is divided into 11 stratigraphic units grouped into two sedimentary units (Figure 2). There is a basal sedimentary unit from the Upper Pleistocene with abundant microfauna [32]; however, evidence of macrofauna and human presence is scarce. The second sedimentary unit comprises the Holocene and is divided into ten stratigraphic units [26]. The cultural affiliation of the Holocene units based on the material records and supported by a large radio-chronological set provide evidence for occupations in the Middle Ages (9th-12th Centuries CE), the Roman Age (2nd Century BCE to 2nd Century CE), the Iron Age I (2360-2740 yr cal BP), Bronze Age (2876-4250 yr cal BP), Chalcolithic (4100-5572 yr cal BP) and Neolithic (5745-7270 yr cal BP) [26]. 


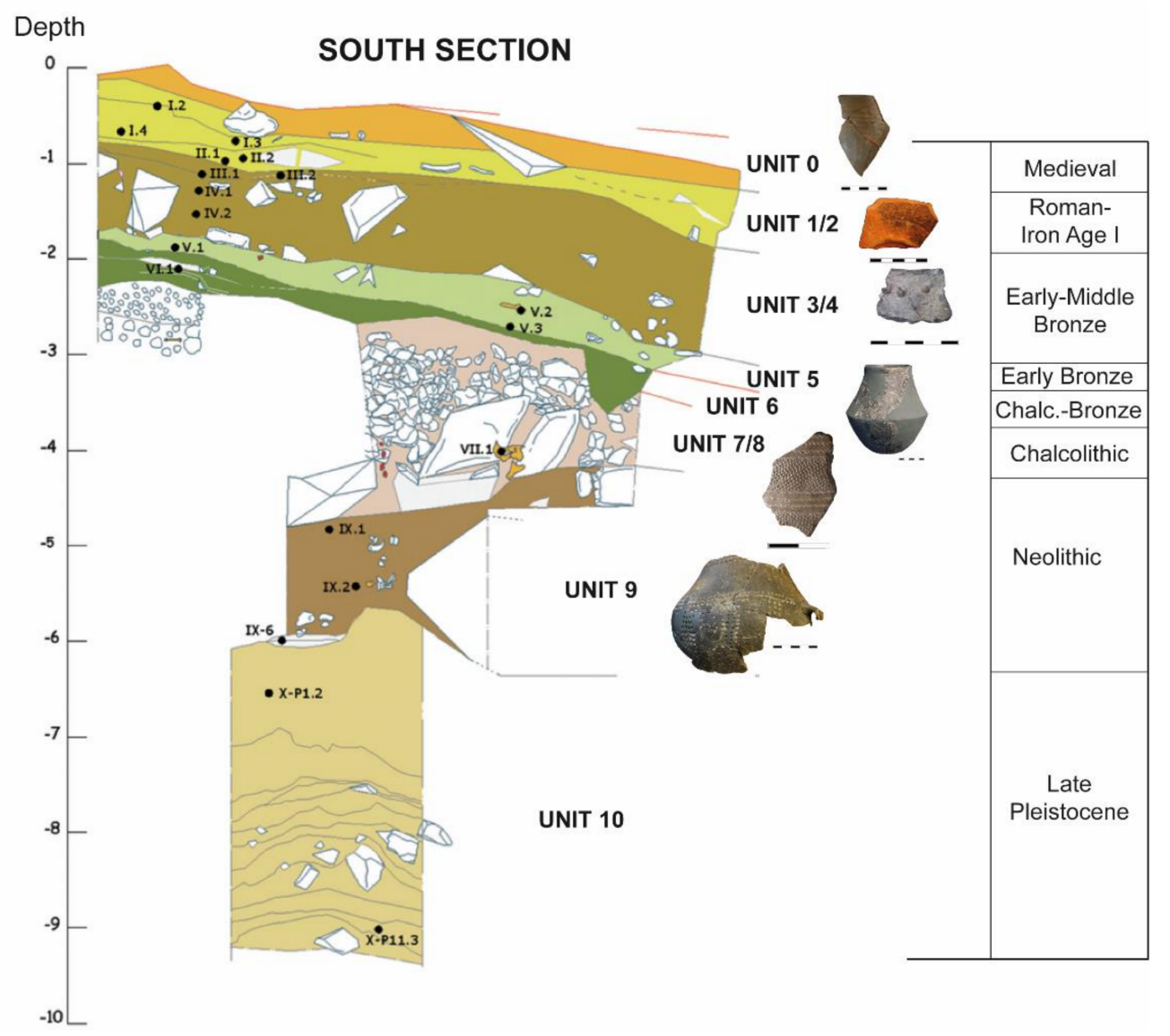

Figure 2. Stratigraphy of El Portalón de Cueva Mayor archaeological site (south profile). Chalcolithic units 7 and 8 represent a Pre-Bell-Beaker funerary context (stone tumulus) (unit 8) and a late Pre-Bell-Beaker and Bell-Beaker stabling/habitational context (unit 7).

This study focuses on small-mammal samples from the Chalcolithic archaeo-stratigraphic levels (Figure 2).

\subsection{Archaeo-Stratigraphic Units and Chronology}

The Chalcolithic stratigraphic units are divided into two phases. The older corresponds to an Early Chalcolithic or Pre-Bell-Beaker funerary context, whereas the Late Pre-Bell-Beaker and Bell-Beaker phase is characterized by a herding and habitat context. The data in this section mainly follow Pérez-Romero et al. [29].

\subsubsection{Early Chalcolithic (Pre-Bell-Beaker) Funerary Context (UE79)}

The burial phase comprises a tumular stacking of decimetric limestone clasts of approximately $8 \mathrm{~m}$ in diameter and $2 \mathrm{~m}$ high in the center. It seems to have an oval shape and is made up of limestone blocks with sizes varying from 40 to $10 \mathrm{~cm}$, and locally they appear to form upward-fining sequences.

The tumular structure was built by a progressive accumulation of limestone clasts in an aggrading (vertical) and prograding manner over a basal surface defined by a floor covered with pottery "pavements", on which there are numerous circular small fire pits filled with partially combusted charcoal fragments (UE79) (Figure 3d). Associated with the fire pits, nearly complete small ceramic bowls are found, along with remains of immature individuals of domestic fauna, mainly lambs, in anatomical connection. Among the limestone clasts and sometimes lying on the floor, different human remains are found, defining funerary contexts with some archaeological elements typical of grave goods (Figure 3e). 

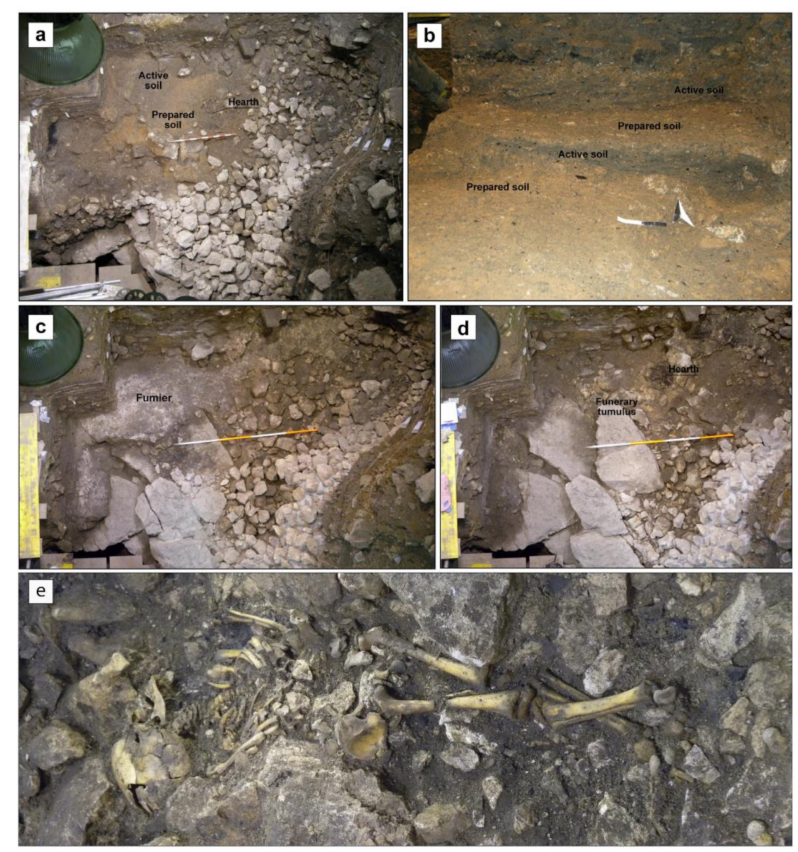

Figure 3. Different archaeological contexts of the Chalcolithic levels of El Portalón de Cueva Mayor site: (a) General view during the excavation of a prepared floor and active soils from the stabling phase. Note the overlapping disposition of these units in relation to the limestone blocks of the funerary tumulus from the previous phase; (b) detailed view of the alternation of prepared clay floors (orange) and active soils (dark) from the habitat/stabling context; (c) partially excavated white ash layer (fumier) covering the funerary tumulus; (d) general view of the funerary tumulus; note the basal large limestone blocks which originated from a collapse of the cave roof; (e) an example of the human remains contained in the funerary tumulus corresponding to an intact burial of a 6-year-old child.

The characteristics of the funerary context suggest this to be the result of repetitive burial activity following a similar funerary pattern over time. Each event appears to have partially disturbed a previous funerary context, with possible collapse of a large part of the roof of the cavity during this period. There is a minimum of eight buried individuals. Furthermore, the later habitation and stable use of the cave seems to have contributed to the disturbance of some of the funerary structures. Under this scenario, human bone remains are a common occurrence, and grave-goods elements often appear scattered among the limestone blocks of the tumular structure $[29,33]$.

\subsubsection{Late Chalcolithic (Late Pre-Bell-Beaker and Bell-Beaker) Habitat and Stabling Context}

Prepared floors (UE23A): They are composed of orange-brown silty/clayey levels of less than $10 \mathrm{~cm}$ thick incorporating small limestone fragments. They include fragmentary archaeological remains (e.g., charcoal, bone, pottery, etc.), mainly at the top. These floors are interpreted as built anthropic floors made of endokarstic silts and clays extracted from the internal galleries of the cave where the pits are still visible. They were likely intended to adequate moist areas for various human activities (living, cooking, etc.). They usually contain anthropic structures, such as hearths and postholes, and appear interspersed with gray sediments belonging to "activity floors" (Figure $3 a, b$ ).

Activity floors (UE23): Grayish clayey units formed by the remains of human activities that took place on them (ashes, charcoal, bone fragments, pottery, vegetal remains, etc.) mixed with fine sediments, trampled and normally deposited above the prepared floors or materials originated from other uses, as stabling (fumiers). They have a variable thickness, from few centimetres to decimetres (Figure $3 a, b$ ). 
Stabling surfaces or fumiers (Layers 214B, 214A, 214, 212, 220, 216): They appear as fine alternating horizontal (millimetric to centimetric) layers with abundant carbonaceous remains (blackish) and ashes (whitish). They represent burned remains of vegetal layers (herbaceous and branches) and manure from livestock stabling areas. These units appear either attached, laterally equivalent or interspersed with the prepared floors and the activity floors (Figure 3c).

Thus, we observe a compartmentalization and an alternation of the uses of the cave space.

\subsubsection{Chronology}

Nine different cereal seed and bone remains from Chalcolithic archaeo-stratigraphic units from the funerary and stabling contexts studied in this work have been radiocarbon dated [26,29,34] (Table 1). More in detail, four human samples and two faunal remains from the funerary context and two cereal seeds (Triticum sp.) and one bone sample from the stabling context were radiocarbon dated using accelerator mass spectrometry (AMS) at Beta Analytic Inc. (Miami, Florida) [34]. Calibration to years cal BP was made by using Oxcal v4.4 software based on the IntCal20 radiocarbon age calibration curve [35].

Table 1. Radiocarbon dates of the Chalcolithic levels of El Portalón de Cueva Mayor sites. Con., conventional; cal, calibrated.

\begin{tabular}{|c|c|c|c|c|c|}
\hline Sample & $\begin{array}{l}\text { Chalcolithic } \\
\text { Cultural Context }\end{array}$ & $\begin{array}{l}\text { Laboratory } \\
\text { Code }\end{array}$ & $\begin{array}{l}\text { Con. Age (yr } \\
\text { BP) }\end{array}$ & $\begin{array}{c}\text { Age } \\
\text { (yr cal BP) }\end{array}$ & Reference \\
\hline Human tibia & Bell-Beaker (UE4) & Beta-269494 & $3900 \pm 40$ & $4423-4158$ & [26] \\
\hline Triticum sp. seed & Pre-Bell Beaker/Stabling (UE209) & Beta-347579 & $4230 \pm 30$ & $4859-4646$ & [26] \\
\hline Triticum sp. seed & Pre-Bell Beaker/Stabling (UE212a) & Beta-347580 & $4280 \pm 30$ & $4957-4732$ & [29] \\
\hline $\begin{array}{l}\text { Human adult proximal } \\
\text { foot phalange }\end{array}$ & Pre-Bell Beaker/Funerary (UE79) & Beta-368290 & $4280 \pm 30$ & $4957-4732$ & {$[34]$} \\
\hline Human tooth & Pre-Bell Beaker/Funerary (UE80) & Beta-337300 & $4300 \pm 30$ & $4960-4830$ & [34] \\
\hline Bos sp. & Pre-Bell Beaker/Funerary (UE80) & Beta-337299 & $4380 \pm 30$ & $5042-4860$ & [29] \\
\hline $\begin{array}{l}\text { Human adult thoracic } \\
\text { vertebra }\end{array}$ & Pre-Bell Beaker/Funerary (UE79) & Beta-368289 & $4400 \pm 30$ & $5214-4862$ & [34] \\
\hline Ovicaprine tooth & Pre-Bell Beaker/Funerary (UE79) & Beta-197389 & $4440 \pm 50$ & $5285-4874$ & [29] \\
\hline $\begin{array}{l}\text { Human fragment of a } \\
\text { right tibial shaft }\end{array}$ & Pre-Bell Beaker/Funerary (UE79) & Beta-368285 & $4460 \pm 40$ & $5294-4886$ & {$[34]$} \\
\hline
\end{tabular}

For a comprehensive chronology/biochronology of the different sites comprising the Atapuerca archaeo-paleontological complex, we refer the reader elsewhere $[4,5]$. Further recent references may enrich this general frame [36-39].

\subsection{Samples}

The studied assemblage includes 12,867 elements, of which 2325 were identified either to the family, genus and/or species level. To obtain the samples, the sediment from the different archaeo-stratigraphic units of the Chalcolithic levels of the site was water-screened, using a stack of sieves of decreasing mesh size $(5,2$ and $0.5 \mathrm{~mm})$. The small mammals were collected from residue coarser than $0.5 \mathrm{~mm}$ in the following proportions: 112 liters from the funerary context, 84 liters from the prepared floors, 90 liters from the activity floors and 91,75 liters from the fumiers.

Fossils were sorted, classified, counted and studied with the aid of a binocular microscope (Nikon SMZ-U; 7x, 20x, and 40x magnifications). Most of the elements are teeth, isolated mandibles, skull fragments and postcranial bones.

The light-to-moderate gastric digestion and scant breakage observed in the smallvertebrate remains indicate that the bones were likely accumulated by an avian predator of category 1 , such as a barn owl (Tyto alba), which is an opportunistic rather than a selective hunter $[2,3]$. However, there are certain instances of heavy-to-extreme modification, which means categories 4 to 5 on the Fernández-Jalvo et al. [3] scale. In these cases, the agents of deposition were most probably small-mammalian carnivores and/or diurnal birds of prey. 


\subsection{Taxonomic Identification and Quantification}

The species/taxon of each small-mammal remain was identified based on cranial and post-cranial diagnostic elements: isolated teeth for the Murinae, Gliridae, Sciuridae and Arvicolinae; mandibles, maxillae and isolated teeth for the Soricidae and Chiroptera; and post-cranial skeleton for the Talpidae. The taxonomic classification follows well-known References [40,41].

The absolute number of elements per taxon was expressed as the number of identified specimens (NISP). The relative ratios of fossil species were established with the minimum number of individuals (MNI), also used as a quantitative measure to evaluate differences among archaeo-stratigraphic units and for paleo-environmental estimations. To determine the MNI, we consider a diagnostic anatomical element, taking into account laterality, e.g., first lower molar in arvicolines and humerus in Talpidae.

\subsection{Statistical Analysis}

Differences in small-mammal relative taxonomic ratios among samples from different archaeo-stratigraphical units/contexts were assessed by an analysis of the variance (ANOVA) on the MNI, with subsequent pairwise t-tests between samples, namely Tukey's (Copenhaver-Holland 1988), Mann-Whitney and Dunn's post hoc, with the latter two with Bonferroni corrections. Statistical analyses were performed by using PAST software v. $3.21[42]$.

\subsection{Paleo-Environmental Estimations}

The information on the habitat affinities of the small-mammal taxa identified at the EC levels of El Portalón was taken from the IUCN Red List of Threatened Species [41] and the bibliography therein; it is summarized in Table 2. The habitats of the wild large mammals mentioned in the Discussion come from the same source. We apply an actualist approach; that is, being a site with a relatively recent chronology, all the fauna are extant, which means that there is little doubt in the species-habitat correlations.

Table 2. Habitat affinities (in green) of small-mammal taxa identified at the early Chalcolithic levels of El Portalón de Cueva Mayor. Fo, forest; Sh, shrubland; Gr, grassland; WI, wetland (inland); RA, rocky areas including caves.

\begin{tabular}{|c|c|c|c|c|c|}
\hline Taxa & Fo & Sh & Gr & WI & RA \\
\hline \multicolumn{6}{|l|}{ Crocidura suaveolens } \\
\hline \multicolumn{6}{|l|}{ Sorex gr. araneus-coronatus } \\
\hline \multicolumn{6}{|l|}{ Sorex minutus } \\
\hline \multicolumn{6}{|l|}{ Neomys fodiens } \\
\hline \multicolumn{6}{|l|}{ Talpa sp. } \\
\hline \multicolumn{6}{|l|}{ Miniopterus schreibersii } \\
\hline \multicolumn{6}{|l|}{ Myotis gr. myotis-blythii } \\
\hline \multicolumn{6}{|l|}{ Arvicola sapidus } \\
\hline \multicolumn{6}{|l|}{ Microtus (T.) } \\
\hline \multicolumn{6}{|l|}{ duodecimcostatus } \\
\hline \multicolumn{6}{|l|}{ Microtus (T.) lusitanicus } \\
\hline \multicolumn{6}{|l|}{ Microtus agrestis } \\
\hline \multicolumn{6}{|l|}{ Microtus arvalis } \\
\hline \multicolumn{6}{|l|}{ Apodemus gr. } \\
\hline \multicolumn{6}{|l|}{ sylvaticus-flavicollis } \\
\hline \multicolumn{6}{|l|}{ Eliomys quercinus } \\
\hline \multicolumn{6}{|l|}{ Sciurus vulgaris } \\
\hline Oryctolagus cuniculus & & & & & \\
\hline
\end{tabular}

\section{Results}

The complete association of small mammals from the Chalcolithic levels of El Portalón includes five eulipotyphlans (Crocidura suaveolens, Sorex gr. araneus-coronatus, S. minutus, Neomys fodiens and Talpa sp.), two chiropterans (Miniopterus shreibersii and Myotis gr. myotisblythii), nine rodents (Arvicola sapidus, Pliomys lenki, Chionomys nivalis, Microtus (Terricola) 
duodecimcostatus, M. (T.) lusitanicus, M. agrestis, M. arvalis, Apodemus gr. sylvaticus-flavicollis, Eliomys quercinus, and Sciurus vulgaris) and one lagomorph (Oryctolagus cuniculus). The detailed list of species, together with the NISP and NMI values per archaeo-stratigraphic unit and context, is shown in Table 3.

Table 3. Number of identified specimens (NISP) and minimal number of individuals (MNI) for the Chalcolithic levels of El Portalón de Cueva Mayor.

\begin{tabular}{|c|c|c|c|c|c|c|c|c|}
\hline \multirow{4}{*}{$\begin{array}{c}\begin{array}{c}\text { Chrono-Cultural } \\
\text { Period }\end{array} \\
\text { Context } \\
\text { Floor } \\
\text { Taxa }\end{array}$} & \multicolumn{2}{|c|}{ Early Chalcolithic } & \multicolumn{6}{|c|}{ Late Chalcolithic } \\
\hline & \multicolumn{2}{|c|}{ Funerary } & \multicolumn{6}{|c|}{ Habitat/Stabling } \\
\hline & & & \multicolumn{2}{|c|}{ Prepared } & \multicolumn{2}{|c|}{ Activity } & \multicolumn{2}{|c|}{ Fumier } \\
\hline & NISP & MNI & NISP & MNI & NISP & MNI & NISP & MNI \\
\hline Crocidura suaveolens & 281 & 83 & 31 & 6 & 46 & 11 & 67 & 25 \\
\hline $\begin{array}{l}\text { Sorex gr. } \\
\text { araneus-coronatus }\end{array}$ & 326 & 79 & 19 & 3 & 67 & 16 & 104 & 38 \\
\hline Sorex minutus & 4 & 3 & 0 & 0 & 0 & 0 & 2 & 2 \\
\hline Neomys fodiens & 3 & 1 & 0 & 0 & 0 & 0 & 0 & 0 \\
\hline Talpa sp. & 10 & 4 & 0 & 0 & 0 & 0 & 7 & 3 \\
\hline Miniopterus schreibersii & 9 & 5 & 1 & 1 & 4 & 3 & 0 & 0 \\
\hline $\begin{array}{c}\text { Myotis gr. } \\
\text { myotis-blythii }\end{array}$ & 27 & 6 & 2 & 1 & 13 & 5 & 5 & 2 \\
\hline Arvicola sapidus & 7 & 4 & 1 & 1 & 0 & 0 & 0 & 1 \\
\hline Pliomys lenki & 0 & 0 & 2 & 1 & 0 & 0 & 0 & 0 \\
\hline Chionomys nivalis & 0 & 0 & 2 & 1 & 0 & 0 & 0 & 0 \\
\hline $\begin{array}{c}\text { Microtus }(T .) \\
\text { duodecimcostatus }\end{array}$ & 15 & 10 & 2 & 2 & 2 & 2 & 7 & 6 \\
\hline Microtus (T.) lusitanicus & 49 & 33 & 2 & 1 & 7 & 5 & 14 & 9 \\
\hline Microtus agrestis & 58 & 36 & 9 & 6 & 16 & 11 & 40 & 25 \\
\hline Microtus arvalis & 95 & 54 & 12 & 10 & 14 & 9 & 37 & 24 \\
\hline $\begin{array}{c}\text { Apodemus gr. } \\
\text { sylvaticus-flavicollis }\end{array}$ & 555 & 121 & 37 & 9 & 94 & 17 & 143 & 33 \\
\hline Eliomys quercinus & 35 & 10 & 3 & 1 & 7 & 3 & 12 & 7 \\
\hline Sciurus vulgaris & 2 & 2 & 1 & 1 & 1 & 1 & 0 & 0 \\
\hline Oryctolagus cuniculus & 8 & 3 & 6 & 2 & 2 & 2 & 0 & 0 \\
\hline Totals & 1484 & 454 & 130 & 46 & 273 & 85 & 438 & 175 \\
\hline
\end{tabular}

In taxonomical terms, the EC funerary context differs from the LC habitat/stabling context in the exclusive presence of $N$. fodiens in the former. The prepared floors differ from any other archaeo-stratigraphic unit in the presence of $P$. lenki and $C$. nivalis. Within the habitat/stabling context, the activity floors differ from the other two units in the absence of A. sapidus; the fumiers, in turn, differ from the other two in the presence of $S$. minutus and Talpa sp. and the absence of O. cuniculus, Sc. vulgaris and M. shreibersii. Figure 4 (EC) and Figure 5 (LC) display diagnostic elements from the different archaeo-stratigraphic units under study, highlighting those taxa which only appear in particular units. 

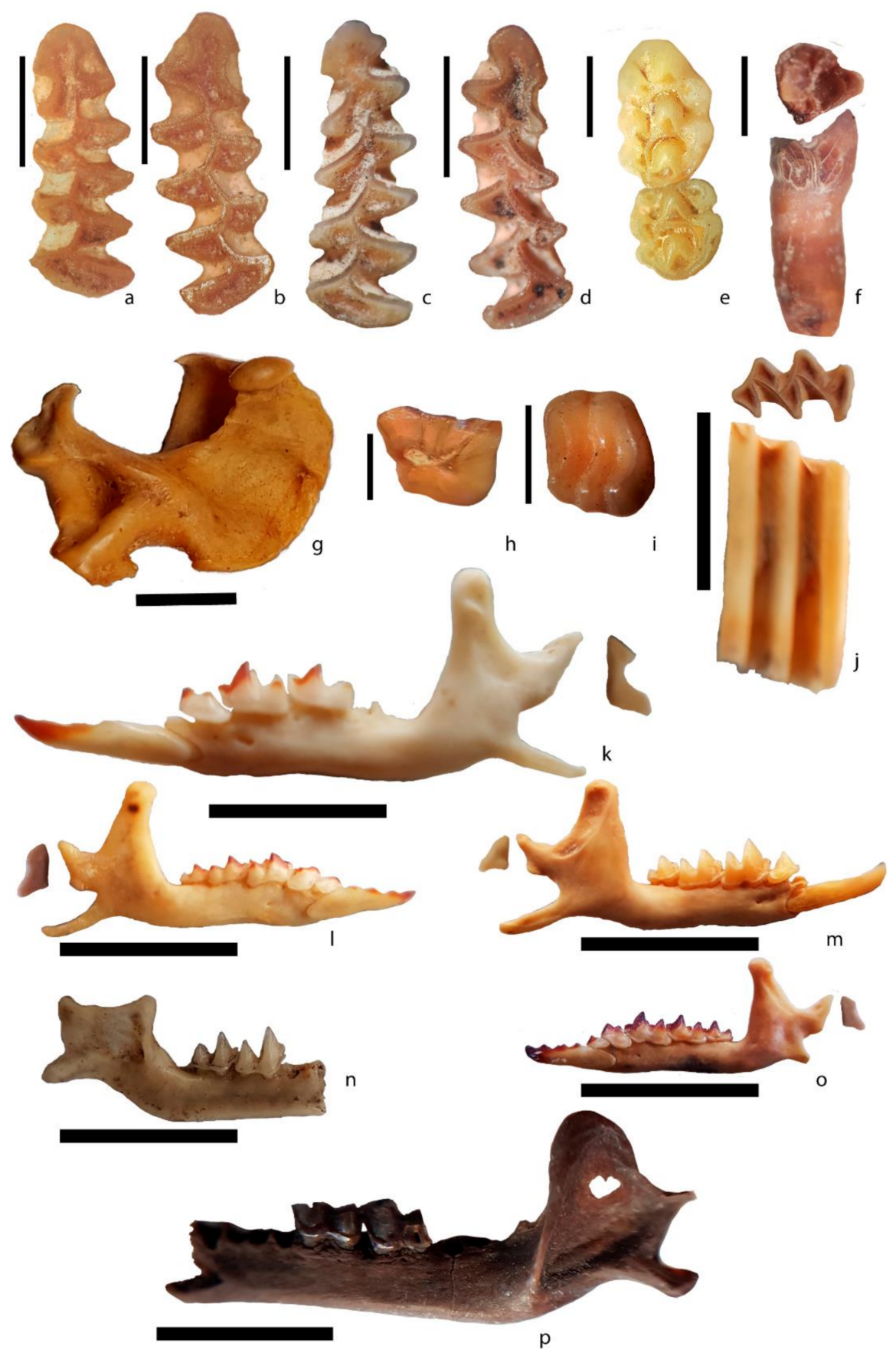

Figure 4. Diagnostic elements of the different taxa present at El Portalón de Cueva Mayor Early Chalcolithic funerary context: (a) Microtus arvalis, left $\mathrm{m} 1$ (occlusal view); (b) M. agrestis, right $\mathrm{m} 1$ (occlusal view); (c) M. (Terricola) duodecimcostatus, left $\mathrm{m} 1$ (occlusal view); (d) M. (T.) lusitanicus, right m1 (occlusal view); (e) Apodemus gr. sylvaticus-flavicollis, right M1M2 (occlusal view); (f) Sciurus vulgaris, left p4 (occlusal and lingual views); (g) Talpa sp., left humerus (posterior view); (h) Oryctolagus cuniculus, right I1 (occlusal view); (i) Eliomys quercinus, left m1 or m2 (occlusal view); (j) Arvicola sapidus, left M1 (occlusal and buccal views); (k) Neomys fodiens, left mandible with i1-p4-m1-m2 (lateral view) and condyle detail (posteroventral view); (1) Sorex gr. araneus-coronatus right mandible with i1-a1-p4-m1-m2-m3 (lateral view) and condyle detail (posteroventral view); (m) Crocidura suaveolens, right mandible with i1-p4-m1-m2-m3 (lateral view) and condyle detail (posteroventral view); (n) Miniopterus schreibersii, right mandible with m2-m3 (lateral view); (o) Sorex minutus, left mandible with i1-a1-p4-m1-m2-m3 (lateral view) and condyle detail (posteroventral view); (p) Myotis gr. myotis-blythii left mandible with m1-m2 (lateral view). Scale bars of $a-f, h, i=1 \mathrm{~mm} ; g, j-p=5 \mathrm{~mm}$. 


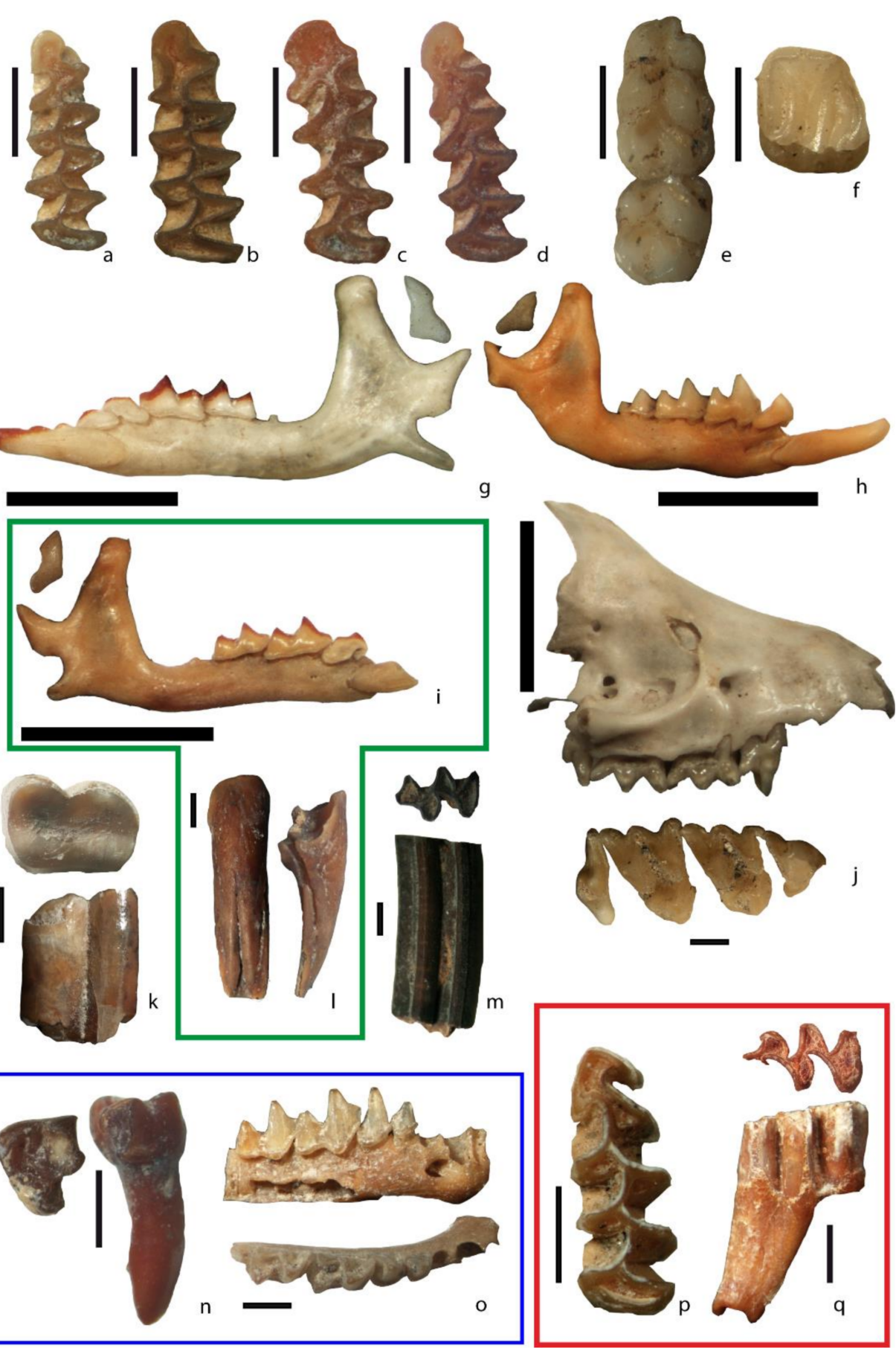

Figure 5. Diagnostic elements of the different taxa present at El Portalón de Cueva Mayor Late Chalcolithic habitational/stabling context, highlighting the taxa which are particular to specific floors: (a) Microtus arvalis, left $\mathrm{m} 1$ (occlusal view); (b) M. agrestis, left m1 (occlusal view); (c) M. (Terricola) duodecimcostatus, left m1 (occlusal view); (d) M. (T.) lusitanicus, left m1 (occlusal view); (e) Apodemus gr. sylvaticus-flavicollis, right m1-m2 (occlusal view); (f) Eliomys quercinus, left m1 or m2 (occlusal view); (g) Sorex gr. araneus-coronatus, right mandible with i1-a1-p4-m1-m2 (lateral view) and condyle detail (posteroventral view); (h) Crocidura suaveolens, left mandible with i1-p4-m1-m2-m3 (lateral view) and condyle detail (posteroventral view); (i) Sorex minutus, right mandible with p4-m1-m2 (lateral view) and condyle detail (posteroventral view); (j) Myotis gr. myotis-blythii right maxilla with P4-M1-M2-M3 (lateral and occlusal views); (k) Oryctolagus cuniculus, left I1 (occlusal and buccal views); (1) Talpa sp., $3^{\text {rd }}$ phalanx (dorsal and lateral views); (m) Arvicola sapidus, right M2 (occlusal and lingual views); (n) Sciurus vulgaris, right p4 (occlusal and posterior views); (o) Miniopterus schreibersii, right mandible with p3-p4-m1-m2 (lateral and occlusal views); (p) Chionomys nivalis, left m1 (occlusal view); (q) Pliomys lenki, left m2 (occlusal and buccal views). Red, only in the prepared floors; green, only in the fumiers; blue, only in the prepared and activity floors. Scale bars of $\mathrm{a}-\mathrm{f}, \mathrm{j}$ (lower), $\mathrm{k}-\mathrm{q}=1 \mathrm{~mm}$; $\mathrm{g}-\mathrm{j}$ (upper) $=5 \mathrm{~mm}$. 
Although the ANOVA test for equal means showed a statistically significant difference among units $(p<0.05)$, the subsequent pairwise t-tests (Tukey's, Mann-Whitney and Dunn's post hoc) revealed that the three units from the LC were not statistically different in their relative taxonomic ratios. That is not the case for the EC Funerary context, which is significantly different from the prepared floors according to all the pairwise t-tests performed ( $p=0.004 ; p=0.03 ; p=0.04$, respectively) and significantly different from the activity floors according to Tukey's $(p=0.01)$.

Crossing data from Table 2 (habitat) and Table 3 (MNI), we can state that, at the EC layers, twelve species represent the forest habitat; eleven, the shrubland; ten, the grassland; five, the inland wetland; and four, the rocky areas, including caves.

\section{Discussion}

Particularly striking is the presence of Pliomys lenki in the Chalcolithic layers of El Portalón. The last records of this species in Europe date to the very end of the Younger Dryas, and they come from Southwestern France and the Cantabrian region of the Iberian Peninsula [5,43]. However, several diagnostic traits (i.e., presence of roots, absence of cement in the re-entrant angles of the crown and large size in relation to the other contemporaneous rooted arvicoline, i.e., Myodes glareolus) indisputably assign the lower molar found at the prepared floors to P. lenki (Figure $5 q$ ). The red pigment of the teeth and the general shape and size of a soricine mandible found at the funerary context (Figure 4k) identify it as belonging to Neomys fodiens and not to its smaller relative N. anomalus.

The presence of P. lenki and Chionomys nivalis confirm the allochthonous endokarstic nature of the clay sediments used in the prepared floors, biostratigraphically attributable to the Upper Pleistocene $[4,5,43]$. Chionomys nivalis has been previously recorded for the latest Pleistocene levels of El Portalón [32], but the last evidences of P. lenki in Atapuerca are from the Middle Pleistocene (i.e., Galería-Cueva de los Zarpazos [4,5]). Nevertheless, as stated before, the latest records of the species in Spain come from the Cantabrian region, dating back prior to the Pleistocene/Holocene transition (e.g., Laminak and El Mirón [43]).

Two bone remains of wild large mammals were found within the prepared floors: an atlas of Bos primigenius (ATP11.UE23a.862) and a distal part of a humerus of Sus scrofa (ATP11.UE23a.861) [44-46]. They might be allochthonous as well, considering that the wild large mammalian fauna is very scarce at the LC levels of El Portalón (accounting for only $2 \%$ of the identified taxa, otherwise largely dominated by domestic species), and that these two species are not present in the underlying EC levels [44]. We cannot be certain on their attribution to the Upper Pleistocene though, a status which absolute dates may eventually assess.

The prepared floors are statistically different from the EC funerary context in terms of their small-mammal relative taxonomic ratios, and arguably different from the activity floors as well. This, together with the presence of $N$. fodiens and the absence of P. lenki and $C$. nivalis in the funerary context, argues in favor of the integrity of this archaeostratigraphic unit, which likely remained unpolluted from overlying LC small-mammal remains percolations.

In spite of the Pleistocene components of the prepared floors, this unit is not statistically different from the other two within the compartmentalized LC habitat/stabling context, and inter-pollution among units cannot be ruled out. This is not surprising for layers that appear interspersed one another.

Comparing the EC and LC contexts as whole individual archaeo-stratigraphic entities, we notice that, even if the amount of residue tested for the LC (266.75 liters) is higher than for the EC (112 liters), the NISP and MNI are clearly higher in the latter, while the number of taxa is slightly lower. Presence of Pleistocene allochthonous components in the LC may explain the latter phenomenon but the former may correspond to a more complex scenario: prepared/activity floors and fumiers are all products of human endeavors; consequently, avian predators and small-mammalian carnivores (main agents responsible for the accumulations of small-mammal remains) were not able to enter the cave with 
the frequency they did when it was used mainly for burying the dead. NISP and MNI at the funerary context are higher than at the habitat/stabling context, and this is likely because humans and stabled animals scared away the predators. When the cave was a sacred space, during the EC, with minimal presence of people, predators were freer to enter. This possibility is supported by the low synanthropic index (35.58\%) obtained elsewhere for these levels [47]. Human-induced disturbances on small-mammal palaeocommunities (i.e., bats) are already known in other cave sites of the Atapuerca complex [10].

Cuenca-Bescós et al. $[4,48]$ defined seven biostratigraphic units for the Sierra de Atapuerca sequence (i.e., Faunal Units (FU) 1-7), the uppermost of them, FU 7, corresponding to the latest Pleistocene small-vertebrate association of El Portalón [32]. An updated version of this biostratigraphic series [5] adds two more faunal units, being FU 8 characterized mainly by the first appearance of the species $M$. (T.) lusitanicus at the Chalcolithic levels of El Portalón [19]. Subsequently, Bañuls-Cardona et al. [37] contributed a detailed study of the small-mammal assemblages from the contiguous cave of El Mirador, with a chronostratigraphy going from the latest Pleistocene up to the late Holocene. In her Ph.D. thesis, Bañuls-Cardona [47] presented a study of the EC (UE79) and LC (UE85) small-mammal associations of El Portalón, mainly intended for the reconstruction of past climate and environments; this study was based on different samples than our own study.

Considering the small-mammal associations and chronologies presented in these previous works and here, we can state that the early Chalcolithic levels of El Portalón contribute the first Holocene records of Crocidura suaveolens, Sorex minutus, Neomys fodiens, N. anomalus, Microtus (Terricola) lusitanicus, M. pyrenaicus, Sciurus vulgaris, Rhinolophus ferrumequinum and Oryctolagus cuniculus in the Sierra de Atapuerca, which are the highest occurrences of these taxa in the sequence as well, together with Miniopterus shreibersii and Myotis gr. myotis-blythii. The latter two appear at El Mirador earlier in the Holocene [37]. Faunal Unit 8 of Atapuerca may be redefined accordingly.

Extending these biostratigraphic remarks to the LC levels could be misleading as their archaeo-stratigraphic units present an evident Pleistocene pollution from the prepared floors; same is applicable for an estimation of the past environment based on these materials. However, we can say that the Pleistocene genesis of the prepared floors is supported by the presence of Chionomys nivalis, a good marker of cold conditions, and the limited number of Apodemus sylvaticus and Eliomys quercinus compared to other units, both these taxa representatives of warm and forested environments [6-8,32,49].

If the EC funerary context remained relatively unbiased until the moment of its excavation, as our results appear to show, then we can give some insights on the environment in the vicinity of the cave, while also keeping in mind that most of the small-mammal samples were accumulated by an opportunistic avian predator randomly sampling the surroundings (see Materials and Methods).

Following Table 2, the general balance obtained from this small-mammal association is that of a patchy landscape dominated by forest, shrubland and grassland, but with a moderate representation of inland wetlands and rocky areas. The estimation is not in contradiction with that obtained by Bañuls-Cardona [47] for the same levels; therefore, they should be considered complementary.

The large wild mammals and other vertebrates identified up to now at the EC funerary context constitute around $2 \%$ of the total (the latter again dominated by domestic taxa by far), including Cervus elaphus (0.99\%), Capreolus capreolus (0.18\%), Vulpes (0.09\%), Mustela sp. $(0.18 \%)$ and Chelonia indet.: (0.45\%) [44]. Cervus elaphus, C. capreolus and V. vulpes currently inhabit woodland, shrubland and grassland zones. Cervus elaphus may be also found in rocky areas, and C. capreolus and $V$. vulpes are found in inland wetlands.

Altogether, this ecological distribution corresponds to generally warm-temperate conditions, similar to those recorded for equivalent ages at the Cantabrian range sites of El Mirón (upper part [6]) and the level III of Peña Larga [49]. Said level III of Peña Larga is especially relevant here, as it represents a collective burial episode during which the cave was minimally or not used as a household at all. As in El Portalón, the rest of the sequence 
of Peña Larga (i.e., early Neolithic to middle Bronze Age) shows evidence of domestic use. Moreover, the level II of Peña Larga, attributed to the late Chalcolithic, exhibits several large alternating lenses, some reddish and some whitish, which probably correspond to the occasional burning of barns or areas occupied by animals [49]. This is again very similar to what we observe at the LC habitat/stabling levels of El Portalón.

El Portalón and Peña Larga similarities are a good example of regional environmental conditions framing similar cultural dynamics (e.g., funerary, habitat and stabling) during the Chalcolithic in north Iberia; this deserves further exploration in other long Holocene archaeo-stratigraphic sequences.

The environmental insights contributed by Bañuls-Cardona [47] and here for El Portalón EC levels (ca. 5294-4732 cal yr BP) fill the chronological gap between the middle (7060-5350 cal yr BP) and Late (4330-3070 cal yr BP) Holocene paleoclimatic and paleoenvironmental reconstructions carried out for the neighbor sequence of El Mirador [37] at the Sierra de Atapuerca.

Bañuls-Cardona [47] also obtained an environmental estimation for the LC levels of El Portalón, but we recommend caution with these results, as the sampled material comes from a unit (UE85) mistakenly regarded as a prepared floor. The stratigraphic Unit 85 actually corresponds to natural sediments deposited in the site during a short human occupation hiatus, archaeologically sterile, just prior to its funerary use, detected in the stratigraphic unit 79. However, as interpreted by Bañuls-Cardona [47], the small-mammal association and paleo-environmental inferences are very similar to those observed during the funerary context of the EC (UE79).

\section{Conclusions}

The associations of small mammals of different archaeo-stratigraphical contexts from the Chalcolithic levels of El Portalón de Cueva Mayor site were successfully used here to characterize them as independent entities. The exclusive presence of certain taxa together with the statistical difference in relative taxonomic ratios point to the integrity and unpolluted condition of the EC Pre-Bell-Beaker Funerary context, which likely remained free of percolations from the overlying LC late Pre-Bell-Beaker and Bell-Beaker habitat and stabling context. The compartmentalization and interspersed arrangement of the different units composing the LC context (prepared floors, activity floors and fumiers) made them prone to inter-pollution, as they do not appear to be statistically different in terms of relative taxonomic ratios.

The presence of Pliomys lenki and Chionomys nivalis in the prepared floors and their sedimentological composition reveal its allochthonous endokarstic nature, being both rodent species that are Upper Pleistocene in age.

The EC levels of El Portalón contribute the first Holocene records of Crocidura suaveolens, Sorex minutus, Neomys fodiens, N. anomalus, Microtus (Terricola) lusitanicus, M. pyrenaicus, Sciurus vulgaris, Rhinolophus ferrumequinum and Oryctolagus cuniculus in the Sierra de Atapuerca archaeo-paleontological complex, which will lead to the redefinition of the Faunal Unit 8 of Atapuerca.

A patchy environment dominated by woodland, shrubland and grassland, with moderate presence of inland wetlands and rocky areas, is inferred from the small-mammal association of the EC levels of El Portalón. This ecological distribution matches well with warm-temperate conditions recorded in other sites of similar age and cultural affiliation from the neighboring Cantabrian region.

The Upper Pleistocene origin of the prepared floors included in the LC habitat and stabling context argues against the use of its small-mammal association either for biostratigraphy or estimation of past environment. 
Author Contributions: Conceptualization, J.R., A.O. and E.I.; methodology, J.R. and A.O.; validation, J.R., A.O., E.I., G.C.-B., M.Á.G.-P., A.P.-R., J.M.C. and J.L.A.; formal analysis and investigation, J.R. and A.O.; resources, E.I., J.M.C. and J.L.A.; data curation, J.R. and A.O.; writing-original draft preparation, J.R., A.O., E.I., G.C.-B. and M.Á.G.-P.; writing-review and editing, all; visualization, J.R., A.O. and E.I.; supervision, J.R.; funding acquisition, all. All authors have read and agreed to the published version of the manuscript.

Funding: This research was supported by the Spanish Ministerio de Ciencia, Innovación y Universidades Project “Geología, Geocronología y Paleobiolología de los yacimientos de la Sierra de Atapuerca VII" (PGC2018-093925-B-C33).

Data Availability Statement: Data are contained within the article.

Acknowledgments: The authors would like to express their gratitude to the El Portalón de Cueva Mayor archaeological site excavation team. M.A.G.-P. has a technical support staff contract (PTA2018015145-I) at the Fundación General de la Universidad de Alcala de Henares-Museo Arqueológico Regional (MAR) financed by the Spanish Ministerio de Economía, Industria y Competitividad and the MAR. We also would like to thank Quaternary administrative editors for their permanent assistance and the comments of two anonymous reviewers to improve the paper.

Conflicts of Interest: The authors declare no conflict of interest.

\section{References}

1. Mellet, J.S. Scatological origin of microvertebrate fossil accumulations. Science 1974, 185, 349-350. [CrossRef] [PubMed]

2. Andrews, P.O. Caves and Fossils: Predation, Preservation and Accumulation of Small Mammal Bones in Caves, with an Analysis of the Pleistocene Cave Faunas from Westbury-Sub-Mendip, Somerset, UK; University of Chicago Press: Chicago, IL, USA, 1990.

3. Fernández-Jalvo, Y.; Andrews, P.; Denys, C.; Sesé, C.; Stoetzel, E.; Marin-Monfort, D.; Pesquero, D. Taphonomy for taxonomists: Implications of predation in small mammal studies. Quat. Sci. Rev. 2016, 139, 138-157. [CrossRef]

4. Cuenca-Bescós, G.; Rofes, J.; López-García, J.M.; Blain, H.-A.; De Marfá, R.J.; Galindo-Pellicena, M.A.; Bennásar-Serra, M.L.; Melero-Rubio, M.; Arsuaga, J.L.; Bermúdez de Castro, J.M.; et al. Biochronology of Spanish Quaternary small vertebrate faunas. Quat. Int. 2010, 212, 109-119. [CrossRef]

5. Cuenca-Bescós, G.; Blain, H.-A.; Rofes, J.; López-García, J.M.; Lozano-Fernández, I.; Galán, J.; Núñez-Lahuerta, C. Updated Atapuerca biostratigraphy: Small-mammal distribution and its implications for the biochronology of the Quaternary in Spain. $C$. R. Palevol 2016, 15, 621-634. [CrossRef]

6. Cuenca-Bescós, G.; Straus, L.G.; González-Morales, M.R.; García-Pimienta, J.C. The reconstruction of past environments through small mammals: From the Mousterian to the Bronze Age in El Mirón Cave (Cantabria, Spain). JAS 2009, 36, 947-955. [CrossRef]

7. López-García, J.M.; Berto, C.; Colamussi, V.; Dalla Valle, C.; Lo Vetro, D.; Luzi, E.; Malavasi, G.; Martini, F.; Sala, B. Palaeoenvironmental and palaeoclimatic reconstruction of the Latest Pleistocene-Holocene sequence from Grotta del Romito (Calabria, southern Italy) using the small-mammal assemblages. Palaeogeogr. Palaeoclimatol. Palaeoecol. 2014, 409, 169-179. [CrossRef]

8. Rofes, J.; Murelaga, X.; Martínez-García, B.; Bailon, S.; López-Quintana, J.C.; Guenaga-Lizasuc, A.; Ortega, L.A.; Zuluaga, M.C.; Alonso-Olazabal, A.; Castaños, J.; et al. The long paleoenvironmental sequence of Santimamiñe (Bizkaia, Spain): 20,000 years of small mammal record from the latest Late Pleistocene to the middle Holocene. Quat. Int. 2014, 339-340, 62-75. [CrossRef]

9. Rofes, J.; Garcia-Ibaibarriaga, N.; Aguirre, M.; Martínez-García, B.; Ortega, L.; Zuluaga, M.C.; Bailon, S.; Alonso-Olazabal, A.; Jone Castaños, J.; Murelaga, X. Combining Small-Vertebrate, Marine and Stable-Isotope Data to Reconstruct Past Environments. Sci. Rep. 2015, 5, 14219. [CrossRef]

10. Galán, J.; Núñez-Lahuerta, C.; López-García, J.; Cuenca-Bescós, G. Did humans disturb bats? Exploring the hominin-chiropter interactions in the Sierra de Atapuerca sites (early to Middle Pleistocene, Spain). Quat. Sci. Rev. 2019, 226, 106018. [CrossRef]

11. Cucchi, T.; Barnett, R.; Martínková, N.; Renaud, S.; Renvoisé, E.; Evin, A.; Sheridan, A.; Mainland, I.; Wickham-Jones, C.; Tougard, C.; et al. The changing pace of insular life: 5000 Years of microevolution in the Orkney vole (Microtus Arvalis Orcadensis). Evolution 2014, 68, 2804-2820. [CrossRef]

12. Rofes, J.; Cucchi, T.; Hanot, P.; Herman, J.; Stephan, P.; Cersoy, S.; Ivan Horácek, I.; Kerr, E.; Allberry, K.; Valenzuela, S.; et al. Postglacial recolonization and Holocene diversification of Crocidura suaveolens (Mammalia, Soricidae) on the north-western fringe of the European continent. Quat. Sci. Rev. 2018, 190, 1-10. [CrossRef]

13. Wood, W.R.; Lee Johnson, D. 9-A Survey of Disturbance Processes in Archaeological Site Formation. In Advances in Archaeological Method and Theory; Schiffer, M.B., Ed.; Academic Press: San Diego, CA, USA, 1978; pp. 315-381.

14. Texier, J. A propos des processus de formation des sites préhistoriques/About prehistoric site formation processes. Paléo, Revue d'Archéologie Préhistorique 2000, 12, 379-386. [CrossRef]

15. Dalland, M.; Carter, S. The evaluation of a prehistoric mound damaged by rabbit burrowing at Maryton Law, Angus. Tayside Fife Archaeol. J. 1998, 4, 20-30.

16. Mallye, J.-B. Badger (Meles meles) remains within caves as an analytical tool to test the integrity of stratified sites: The contribution of Unikoté Cave (Pyrénées-Atlantiques, France). J. Taphon. 2011, 9, 15-36. 
17. Pelletier, M.; Brugal, J.-P.; Cochard, D.; Lenoble, A.; Mallye, J.-B.; Royer, A. Identifying fossil rabbit warrens: Insights from a taphonomical analysis of a modern warren. JAS Rep. 2016, 10, 331-344. [CrossRef]

18. Rofes, J.; Cersoy, S.; Zazzo, A.; Royer, A.; Nicod, P.-Y.; Laroulandie, V.; Langlais, M.; Pailler, Y.; Leandri, C.; Leandri, F.; et al. Detecting stratigraphical issues using direct radiocarbon dating from small-mammal remains. J. Quat. Sci. 2020, 35, 505-513. [CrossRef]

19. Ordiales, A.; Rofes, J.; Iriarte, E.; Mardones, V.; Cuenca-Bescós, G.; Carretero, J.M.; Arsuaga, J.L.; García-Ibaibarriaga, N. Small mammals as tools to characterize archaeological contexts in the Chalcolithic of Portalón de Cueva Mayor (Atapuerca, Burgos, Spain). In Proceedings of the 1st Young Natural History Scientists' Meeting, Paris, France, 12-14 February $2014 ;$ p. 12.

20. Carbonell, E.; Bermúdez de Castro, J.M.; Arsuaga, J.L.; Díez, J.C.; Rosas, A.; Cuenca-Bescós, G.; Sala, R.; Mosquera, M.; Rodríguez, X.P. Lower Pleistocene hominids and artifacts from Atapuerca TD6 (Spain). Science 1995, 269, 826-830. [CrossRef]

21. Carbonell, E.; Bermúdez de Castro, J.M.; Parés, J.M.; Pérez-González, A.; Cuenca-Bescós, G.; Olle, A.; Mosquera, M.; Huguet, R.; van der Made, J.; Rosas, A.; et al. The first hominin of Europe. Nature 2008, 452, 465-470. [CrossRef]

22. Arsuaga, J.L.; Bermúdez de Castro, J.M.; Carbonell, E. (Eds.) The Sima de los Huesos hominid Site. J. Hum. Evol. 1997, 33, $105-421$. [CrossRef]

23. Bermúdez de Castro, J.M.; Carbonell, E.; Arsuaga, J.L. (Eds.) Gran Dolina Site: TD6 Aurora Stratum (Burgos, Spain). J. Hum. Evol. 1999, 37, 309-700.

24. Clark, G.; Straus, L.G.; Burton, S.S.; Jackson-Clark, V. The North Burgos Archaelogical Survey: An inventory of cultural remains. In The North Burgos Archaelogical Survey. Bronze and Iron Age archaeology on the Meseta del Norte (Province of Burgos, North-Central Spain) 19, 18 156; Clark, G., Ed.; Arizona State University, Department of Antropology: Tempe, AZ, USA, 1979.

25. Apellaniz, J.M.; Domingo, D. Estudios sobre Atapuerca (Burgos): II. Los materiales de superficie del Santuario de la Galería del Sílex. Cuad. Arqueol. Univ. Deusto 1987, 10, 1-342.

26. Carretero, J.M.; Ortega, A.I.; Juez, L.; Pérez-González, A.; Arsuaga, J.L.; Pérez, R.; Ortega, M.C. A Late Pleistocene-Early Holocene archaeological sequence of Portalón de Cueva Mayor (Sierra de Atapuerca, Burgos, Spain). Munibe 2008, 59, 67-80.

27. Pérez-Romero, A.; Carretero, J.M.; Juez, L.; Ortega, A.I.; Ortega, M.C.; Arsuaga, J.L. Una dobla almohade del Siglo XIII en el yacimiento de El portalón de Cueva Mayor, Sierra de Atapuerca (Burgos). Nvmisma 2010, 254, 85-106.

28. Pérez-Romero, A.; Carretero, J.M.; Alday, A.; Arsuaga, J.L. La Cerámica Protohistórica e Histórica en el yacimiento de El Portalón de Cueva Mayor, Sierra de Atapuerca, Burgos. Bol. Soc. Esp. Ceram. Vidr. 2013, 52, 183-193. [CrossRef]

29. Pérez-Romero, A.; Iriarte, E.; Galindo-Pellicena, M.A.; García-González, R.; Rodríguez, L.; Castilla, M.; Francés-Negro, M.; Santos, E.; Valdiosera, C.; Arsuaga, J.L.; et al. An unusual Pre-bell beaker copper age cave burial context from El Portalón de Cueva Mayor site (Sierra de Atapuerca, Burgos). Quat. Int. 2017, 433, 142-155. [CrossRef]

30. Vergés, J.M.; Allué, E.; Angeluccí, D.E.; Cebriá, A.; Fontanals, M.D.; Mányanos, A.; Montero, S.; Moral, S.; Vaquero, M.; Zaragoza, J. La sierra de Atapuerca durante el Holoceno: Datos preliminares sobre las ocupaciones de la Edad del Bronce en la cueva de Mirador (Ibeas de Juarros, Burgos). Trab. Prehist. 2002, 59, 107-126. [CrossRef]

31. Vergés, J.M.; Allué, E.; Angeluccí, D.E.; Burjachs, F.; Carrancho, A.; Cebriá, A.; Expósito, I.; Fontanals, M.; Moral, S.; Rodríguez, A.; et al. Los niveles neolíticos de la cueva del Mirador (Sierra de Atapuerca Burgos): Nuevos datos sobre la implantación y el desarrollo de la economía agropecuaria en la submeseta norte. In Proceedings of the IV Peninsular Neolithic Congres, MARQ, Alicante, Spain; Hernández, M.S., Soler, J.A., López, J.A., Eds.; Museo Arqueológico de Alicante, Diputación de Alicante: Alicante, Spain, 2008; pp. 418-427.

32. López-García, J.M.; Blain, H.-A.; Cuenca-Bescós, G.; Ruiz-Zapata, M.B.; Dorado-Valiño, M.; Gil-García, M.J.; Valdeolmillos, A.; Ortega, A.I.; Carretero, J.M.; Arsuaga, J.L.; et al. Palaeoenvironmental and palaeoclimatic reconstruction of the Latest Pleistocene of El Portalón Site, Sierra de Atapuerca, northwestern Spain. Palaeogeogr. Palaeoclimatol. Palaeoecol. 2010, 292, 453-464. [CrossRef]

33. Castilla, M.; Carretero, J.M.; Gracia, A.; Arsuaga, J.L. Evidence of Rickets and/or Scurry in a complete Chalcolithic Child Skeleton from the El Portalón Site (Sierra de Atapuerca, Spain). JASs Rep. 2014, 92, 1-16.

34. Günther, T.; Valdiosera, C.; Malmström, H.; Ureña, I.; Rodriguez-Varela, R.; Osk Sverrisdóttir, O.; Daskalaki, E.A.; Skoglund, P.; Naidoo, T.; Svensson, E.M.; et al. Ancient genomes link early farmers from Atapuerca in Spain to modern-day Basques. Proc. Natl. Acad. Sci. USA 2015. [CrossRef]

35. Reimer, P.J.; Austin, W.E.N.; Bard, E.; Bayliss, A.; Blackwell, P.G.; Ramsey, C.B.; Butzin, M.; Cheng, H.; Edwards, R.L.; Friedrich, M.; et al. The IntCal20 Northern Hemisphere Radiocarbon Age Calibration Curve (0-55 cal kBP). Radiocarbon 2020, 62, 725-757. [CrossRef]

36. Arsuaga, J.L.; Gómez-Olivencia, A.; Sala, N.; Martínez-Pillado, V.; Pablos, A.; Bonmatí, A.; Pantoja, A.; Lira, J.; Alcázar de Velasco, A.; Ortega, A.I.; et al. Evidence of paleoecological changes and Mousterian occupations at the Galería de las Estatuas site, Sierra de Atapuerca, northern Iberian plateau, Spain. Quat. Res. 2017, 88, 345-367. [CrossRef]

37. Bañuls-Cardona, S.; López-García, J.M.; Morales-Hidalgo, J.I.; Cuenca-Bescós, G.; Vergés, J.M. Late Glacial to Late Holocene palaeoclimatic and palaeoenvironmental reconstruction of El Mirador cave (Sierra de Atapuerca, Burgos, Spain) using the small-mammal assemblages. Palaeogeogr. Palaeoclimatol. Palaeoecol. 2017, 471, 71-81. [CrossRef]

38. Cuenca-Bescós, G.; Rossell, J.; Morcillo-Amo, A.; Galindo-Pellicena, M.A.; Santos, E.; Moya-Costa, R. Beavers (Castoridae, Rodentia, Mammalia) from the Quaternary sites of the Sierra de Atapuerca, in Burgos, Spain. Quat. Int. 2017, 433, 263-277. [CrossRef] 
39. Benito-Calvo, A.; Ortega, A.I.; Pérez-González, A.; Campaña, I.; Bermúdez de Castro, J.M.; Carbonell, E. Palaeogeographical reconstruction of the Sierra de Atapuerca Pleistocene sites (Burgos, Spain). Quat. Int. 2017, 433, 379-392. [CrossRef]

40. Wilson, D.E.; Reeder, D.-A.M. Mammal Species of the World. In A Taxonomic and Geographic Reference; The Johns Hopkins University Press: Baltimore, MD, USA, 2005.

41. IUCN Red List of Threatened Species. Available online: https://www.iucnredlist.org/ (accessed on 23 February 2021).

42. Hammer, Ø.; Harper, D.A.T.; Ryan, P.D. PAST: Paleontological Statistics Software Package for education and data analysis. Palaeontol. Electron. 2001, 4, 9. Available online: http://folk.uio.no/ohammer/past/ (accessed on 1 October 2018).

43. Cuenca-Bescós, G.; Straus, L.G.; García-Pimienta, J.C.; González Morales, M.R.; López-García, J.M. Late Quaternary small mammal turnover in the Cantabrian Region: The extinction of Pliomys lenki (Rodentia, Mammalia). Quat. Int. 2010, 212, 129-136. [CrossRef]

44. Galindo-Pellicena, M.A. Estudio de la macrofauna de los niveles holocenos del yacimiento de El Portalón (sierra de Atapuerca, Burgos). Ph.D. Thesis, Department of Paleontology, Complutense University of Madrid, Madrid, Spain, 2014.

45. Galindo-Pellicena, M.A.; Arsuaga, J.L.; Carretero, J.M. Pig management in the Chalcolithic and Bronze Age periods at the El Portalón site: Integration in the Iberian context. Quat. Int. 2019, 515, 138-149. [CrossRef]

46. Galindo-Pellicena, M.A.; Arsuaga, J.L.; Pérez-Romero, A.; Iriarte, E.; DeGaspar, I.; Carretero, J.M. Metrical analysis of bovine bone remains from the Neolithic to the Bronze Age at the El Portalón site (Atapuerca, Burgos) in the Iberian context. Quat. Int. 2020, 566-567, 211-213. [CrossRef]

47. Bañuls-Cardona, S. Human Impact on Small-Mammals from Late Glacial to Late Holocene of Western Mediterranean Region: New Environmental and Climate Approach. Ph.D. Thesis, Università degli Studi di Ferrara, Ferrara, Italy, 2017.

48. Cuenca-Bescós, G.; García, N. Biostratigraphic succession of the Early and Middle Pleistocene mammal faunas of the Atapuerca cave sites (Burgos, Spain). Cour. Forschunginst. Senckenberg 2007, 259, 99-110.

49. Rofes, J.; Zuluaga, M.C.; Murelaga, X.; Fernández-Eraso, J.; Bailon, S.; Iriarte, M.J.; Ortega, L.A.; Alonso-Olazabal, A. Palaeoenvironmental reconstruction of the early Neolithic to middle Bronze Age Peña Larga rock shelter (Álava, Spain) from the small mammal record. Quat. Res. 2013, 79, 158-167. [CrossRef] 